\title{
Masalah Peredaman Gangguan (Disturbance Attenuation Problem) Untuk Sistem Linear Time Invariant Lingkar Terbuka Dengan Pendekatan Permainan Dinamis
}

\author{
Muhammad Wakhid Musthofa \\ Program Studi Matematika, Fakultas Sains dan Teknologi, Universitas Islam Negeri Sunan Kalijaga \\ Yogyakarta, JI. Marsda Adisucipto Yogyakarta 55281
}

Korespondensi; Email: mwakhid_m@yahoo.com

\begin{abstract}
Abstrak
Makalah ini membahas tentang desain kendali robust untuk mengatasi peredaman gangguan yang terjadi pada suatu sistem dinamik Linear Time Invariant (LTI). Tidak seperti metode yang biasa dilakukan dalam mendesain kendali robust, dalam makalah ini kendali robust didesain dengan menggunakan pendekatan permainan dinamis. Disamping desain kendali, dalam makalah ini juga dibahas batas terkecil dari parameter $\gamma$ sebagai level peredaman gangguan. Selanjutnya disajikan contoh numerik desain kendali robust melalui pendekatan domain frekuensi dan permainan dinamis.
\end{abstract}

Kata Kunci: Masalah Peredaman Gangguan; Kendali Robust; Permainan Dinamis; sistem LTI.

\begin{abstract}
This paper discusses the design of robust control to overcome disturbance attenuation in a dynamic system linear time invariant (LTI). Unlike the usual method in designing robust control, robust control in this paper is designed using dynamic game approach. Besides the design of the control, in this paper also discussed the small end of the parameters as the level of interference suppression. Further presented numerical example of robust control design via frequency domain approach and dynamic game.
\end{abstract}

Keywords: Interference Suppression problem; Robust Control; Dynamic Games; LTI system.

\section{Pendahuluan}

Gangguan adalah suatu hal yang hampir pasti dialami oleh semua sistem. Gangguan dapat berasal dari faktor eksternal sistem seperti turbulensi angin pada pesawat terbang yang sedang mengudara. Selain itu gangguan dapat pula berasal dari faktor internal sistem sebagai akibat ketidakakuratan pemodelan seperti fluktuasi inflasi akibat ketidakakuratan pemodelan sistem makro ekonomi (Engwerda, 2005). Tersaji dalam bentuk apapun, gangguan selalu merugikan sistem. Oleh karena itu permasalahan yang banyak dihadapi oleh desainer kendali adalah mendesain kendali yang mampu mengatasi gangguan-gangguan yang mungkin muncul pada sistem.

Fokus dari masalah redaman gangguan (disturbance attenuation problem) adalah mendesain sebuah kendali optimal (yang meminimalkan biaya pengendalian) untuk meredam berbagai tipe gangguan yang bermacam-macam yang muncul pada sistem yang tidak hanya dapat diaplikasikan pada suatu jenis plant dengan masukan tunggal yang tidak diketahui, akan tetapi desain kendali tersebut mampu diaplikasikan pada berbagai jenis plant sehingga tujuan pengendalian yang diinginkan dapat tercapai. Tingkat kuantitas gangguan yang teredam ditunjukkan oleh suatu parameter yang menyatakan nilai minimax dari kuantitas output terkendali dengan kuantitas gangguan yang keduanya dinyatakan dalam bentuk norm ruang $\mathcal{H}_{\infty}$ dari fungsi transfer sistemnya (Basar Bernhard, 1995).

Masalah redaman gangguan merupakan bagian dari masalah desain kendali robust. Kendali robust adalah sebuah jenis kendali yang kokoh terhadap gangguan dan ketidakpastian yang dialami oleh suatu sistem. Dalam dua dekade ini pengembangan metode desain sistem kendali yang robust masih 
menjadi hal utama yang dikerjakan oleh para ilmuwan yang tergabung komunitas kontrol baik pengembangan dalam aspek teoritis maupun aspek praktis (Xu dan Lam, 2006).

Dalam perkembangannya konsep teori kendali optimal telah dapat digeneralisasikan dalam teori permainan yang memunculkan topik bahasan permainan dinamis (differential game) (Engwerda, 2005). Dalam topik ini beberapa pemain mempunyai tujuan untuk meminimumkan fungsi ongkos yang mereka miliki, dan diantara mereka terdapat konflik dalam mencapai tujuannya. Untuk mendapatkan fungsi ongkos yang minimum masing-masing pemain harus memilih kendali yang sesuai berdasarkan informasi permainan yang mereka miliki pada himpunan kendali yang diperkenankan dalam sistem dinamik linear yang mendasarinya. Tipe permainan yang diperlukan dalam makalah ini adalah permainan dinamis dua pemain berjumlah nol. Dalam tipe ini fungsi ongkos yang dimiliki oleh pemain kedua adalah negatif dari fungsi ongkos pemain pertama, sehingga jika kedua fungsi ongkos ini dijumlahkan akan menghasilkan nilai nol. Selain itu, tipe permainan juga dibatasi pada permainan dinamis linear kuadratik (linear quadratic differential game).

Hingga sejauh ini masalah peredaman gangguan dengan mendesain kendali robust masih dikerjakan dalam domain frekuensi. Makalah ini akan mengembangkan konsep tersebut dengan menggunakan pendekatan teori permainan dinamis.

\section{Desain Kendali Robust}

Kendali robust adalah tipe kendali yang tahan terhadap gangguan dan ketidakpastian yang terdapat pada suatu plant atau sistem yang dikendalikan. Ukuran ketahanan kendali terhadap gangguan dan ketidakpastian diukur menggunakan norm dalam ruang $\mathcal{H}_{\infty}$. Berikut ini disajikan desain kendali robust untuk sistem Linear Time Invariant (LTI) dengan menggunakan pendekatan domain frekuensi sebagai pendekatan yang lazim dilakukan. Diberikan sistem LTI:

$$
\begin{aligned}
& \dot{x}(t)=A x(t)+B_{1} u(t)+B_{2} w(t), \quad x\left(t_{0}\right)=x_{0} \\
& y(t)=C_{1} x(t)+D_{12} w(t) \\
& z(t)=C_{2} x(t)+D_{21} u(t),
\end{aligned}
$$

dengan $x \in \mathrm{R}^{n}, A \in \mathrm{R}^{n \times n}, \quad B_{i} \in \mathrm{R}^{n \times m_{i}}, u \in \mathrm{R}^{m_{1}}, \quad w \in \mathrm{R}^{m_{2}}, \quad i=1,2$. Vektor $u(t)=\mu(y(t))$ dengan $\mu \in M$ (M merupakan himpunan semua kendali yang diperkenankan bagi sistem (1)) merupakan masukan kendali bagi sistem, $w(t)$ adalah gangguan yang muncul dalam sistem, $y(t)$ adalah output terukur dan $z(t)$ adalah output teregulasi bagi sistem. Dalam bentuk relasi input-output, sistem (1) di atas disajikan dalam bentuk fungsi transfer:

$$
\begin{aligned}
G_{z w} & =\left[\begin{array}{l}
C_{1} \\
C_{2}
\end{array}\right](s I-A)^{-1}\left[\begin{array}{ll}
B_{1} & B_{2}
\end{array}\right]+\left[\begin{array}{cc}
0 & D_{12} \\
D_{21} & 0
\end{array}\right] \\
& =\left[\begin{array}{c|cc}
A & B_{1} & B_{2} \\
\hline C_{1} & 0 & D_{12} \\
C_{2} & D_{21} & 0
\end{array}\right]=\left[\begin{array}{ll}
G_{11} & G_{12} \\
G_{21} & G_{22}
\end{array}\right] .
\end{aligned}
$$

Bentuk blok diagram dari sistem (1) disajikan dengan gambar di bawah,

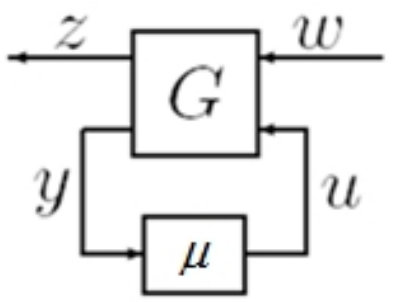

Gambar 1 Representasi sistem 1.

atau dengan persamaan berikut:

$$
\left[\begin{array}{l}
z(t) \\
y(t)
\end{array}\right]=\left[\begin{array}{ll}
G_{11} & G_{12} \\
G_{21} & G_{22}
\end{array}\right]\left[\begin{array}{l}
w(t) \\
u(t)
\end{array}\right]
$$




$$
u(t)=\mu y(t) .
$$

Dalam kerangka linear fractional transformation (LFT) persamaan (2) di atas dirumuskan dengan:

$$
\begin{aligned}
F_{l}(G, \mu) & =G_{11}+G_{12}\left(I-\mu \cdot G_{22}\right)^{-1}\left(\mu \cdot G_{21}\right) \\
& :=G_{\mu}(w) .
\end{aligned}
$$

Masalah yang ingin diselesaikan adalah mendesain mekanisme kendali yang memungkinkan yang akan menjaga $z(t)$ cukup kecil terhadap kemungkinan munculnya gangguan $w(t)$ pada sistem. Perbandingan antara kuantitas $z(t)$ dan $w(t)$ dinyatakan dalam bentuk norm

$$
\frac{\|z(t)\|}{\|w(t)\|}=:\left\|G_{z w}\right\|=\left\|G_{\mu}(w)\right\| .
$$

Selanjutnya didefinisikan matriks Hamiltonian untuk sistem (1) di atas

$$
H_{\infty}:=\left[\begin{array}{cc}
A & \gamma^{-2} B_{1} B_{1}^{*}-B_{2} B_{2}^{*} \\
-C_{1}^{*} C_{1} & -A^{*}
\end{array}\right] \text { dan } J_{\infty}:=\left[\begin{array}{cc}
A^{*} & \gamma^{-2} C_{1}^{*} C_{1}-C_{2}^{*} C_{2} \\
-B_{1} B_{1}^{*} & -A
\end{array}\right]
$$

Untuk mencari solusi dari persamaan aljabar Riccati yang bersesuaian dengan matriks Hamiltonian di atas, didefinisikan pemetaan Riccati (Ric) sebagai berikut Ric : dom (Ric) $\subseteq \mathrm{R}^{2 n \times 2 n} \rightarrow \mathrm{R}^{n \times n}$ dengan dom (Ric) beranggotakan semua matriks Hamiltonian (3). Pemetaan tersebut memetakan semua matriks Hamiltonian ke matriks $X=\operatorname{Ric}(H)>0$ sebagai solusi dari persamaan aljabar Riccati yang bersesuaian dengan matriks Hamiltonian (3).

Masalah kendali optimal $\mathcal{H}_{\infty}$ dapat dirumuskan sebagai mencari semua kendali yang diperkenankan (admissible controllers) $\mu(s)$ sedemikian sehingga $\left\|G_{z w}\right\|_{\infty}$ minimum. Untuk kepentingan praktis, terkadang tidak diinginkan mencari kendali optimal akan tetapi hanya kendali suboptimal $\mathcal{H}_{\infty}$ saja. Masalah tersebut dapat dirumuskan sebagai mencari semua kendali yang diperkenankan (admissib/e controllers $) \mu(s)$ sedemikian sehingga $\left\|G_{z w}\right\|_{\infty}<\gamma$, untuk suatu $\gamma$ yang diberikan. Untuk merumuskan teorema kendali suboptimal $\mathcal{H}_{\infty}$, pada sistem (1) di atas diasumsikan beberapa hal berikut dipenuhi.

1. $\left(A, B_{1}\right)$ dapat distabilkan dan $\left(C_{1}, A\right)$ terdeteksi.

2. $\left(A, B_{2}\right)$ terkendali dan $\left(C_{2}, A\right)$ teramati.

3. $D_{21}^{*}\left[\begin{array}{ll}C_{2} & D_{21}\end{array}\right]=\left[\begin{array}{ll}0 & I\end{array}\right]$

4. $\left[\begin{array}{c}B_{2} \\ D_{12}\end{array}\right] D_{12}^{*}=\left[\begin{array}{l}0 \\ I\end{array}\right]$

Selanjutnya, teorema berikut menyatakan keberadaan kendali suboptimal $\mathcal{H}_{\infty}$.

Teorema 1. (Zhou, 1998) Terdapat kendali yang diperkenankan untuk sistem (1) di atas sedemikian sehingga $\left\|G_{z w}\right\|_{\infty}<\gamma$ jika dan hanya jika kondisi di bawah ini dipenuhi

i. $\quad H_{\infty} \in \operatorname{dom}(\mathrm{Ric})$ dan $X_{\infty}>0$, dengan $X_{\infty}$ adalah solusi dari persamaan aljabar Riccati yang bersesuaian dengan matriks Hamiltonian $H_{\infty}$. 
ii. $J_{\infty} \in \operatorname{dom}(\mathrm{Ric})$ dan $Y_{\infty}>0$, dengan $Y_{\infty}$ adalah solusi dari persamaan aljabar Riccati yang bersesuaian dengan matriks Hamiltonian $J_{\infty}$.

iii. $\rho\left(X_{\infty} Y_{\infty}\right)<\gamma^{2}$

Lebih lanjut, jika kondisi di atas dipenuhi, salah satu bentuk kendali suboptimal $\mathcal{H}_{\infty}$ adalah

$$
\mu_{s u b}(s)=\left[\begin{array}{c|c}
\hat{A}_{\infty} & -Z_{\infty} L_{\infty} \\
\hline F_{\infty} & 0
\end{array}\right],
$$

dengan $\hat{A}_{\infty}=A+\gamma^{-2} B_{1} B_{1}^{*} X_{\infty}+B_{2} F_{\infty}+Z_{\infty} L_{\infty} C_{2}, F_{\infty}=-B_{2}^{*} X_{\infty}, L_{\infty}=-Y_{\infty} C_{2}^{*}, \quad$ dan $Z_{\infty}=\left(I-\gamma^{-2} Y_{\infty} X_{\infty}\right)^{-1}$.

Untuk dapat membuktikan Teorema 1 di atas, diperlukan beberapa teorema dan lemma berikut. Pertama, Lemma berikut terkait dengan suatu fakta dalam teori matriks.

Lemma 2. (Zhou, 1998) Diberikan $X \in \sqcup^{n \times n}, Y \in \sqcup^{n \times n}$ dengan $X=X^{T}>0 \quad$ dan $Y=Y^{T}>0$. Misalkan $k$ bilangan bulat positif, maka terdapat matriks

$$
X_{12} \in \sqcup^{n \times k},\left[\begin{array}{cc}
X & X_{12} \\
X_{12}^{T} & X_{2}
\end{array}\right]>0 \text { dan }\left[\begin{array}{cc}
X & X_{12} \\
X_{12}^{T} & X_{2}
\end{array}\right]^{-1}=\left[\begin{array}{cc}
Y & * \\
* & *
\end{array}\right]
$$

jika dan hanya jika

$$
\left[\begin{array}{cc}
X & I_{n} \\
I_{n} & Y
\end{array}\right] \geq 0 \quad \text { dan } \operatorname{rank}\left[\begin{array}{cc}
X & I_{n} \\
I_{n} & Y
\end{array}\right] \leq n+k
$$

Tanda * menotasikan elemen yang tidak diperhatikan.

Selanjutnya diberikan lemma yang menyatakan karakterisasi ketaksamaan matriks dan kaitannya dengan kendali sistem.

Lemma 3. (Zhou, 1998) Terdapat kendali yang diperkenankan berorde $k$ sede- mikian sehingga $\left\|G_{z w}\right\|_{\infty}<\gamma$ jika dan hanya jika kondisi-kondisi berikut dipenuhi.

i. Terdapat matriks $Y_{1}>0$ yang memenuhi ketaksamaan

$$
A Y_{1}+Y_{1} A^{*}+Y_{1} C_{1}^{*} C_{1} Y_{1} / \gamma^{2}+B_{1} B_{1}^{*}-\gamma^{2} B_{2} B_{2}^{*}<0
$$

ii. Terdapat matriks $Y_{1}>0$ yang memenuhi ketaksamaan

$$
X_{1} A+A^{*} X_{1}+X_{1} B_{1} B_{1}^{*} X_{1} / \gamma^{2}+C_{1}^{*} C_{1}-\gamma^{2} C_{2}^{*} C_{2}<0
$$

iii. $\left[\begin{array}{cc}X_{1} / \gamma & I_{n} \\ I_{n} & Y_{1} / \gamma\end{array}\right] \geq 0 \quad$ dan $\operatorname{rank}\left[\begin{array}{cc}X_{1} / \gamma & I_{n} \\ I_{n} & Y_{1} / \gamma\end{array}\right] \leq n+k$.

Teorema di bawah mengulas keterkaitan antara solusi dari persamaan aljabar Riccati dengan solusi dari ketaksamaan aljabar Riccati.

Teorema 4. (Zhou, 1998) Diberikan matriks $R \geq 0$ dan misalkan $(A, R)$ terkendali dan terdapat matriks $X=X^{*}$ yang memenuhi

$$
Q(X):=X A+A^{*} X+X R X+Q<0 .
$$


Maka, terdapat terdapat solusi $X_{+}>X$ untuk persamaan Riccati

$$
X_{+} A+A^{*} X_{+}+X_{+} R X_{+}+Q=0,
$$

sedemikian sehingga matriks $A+R X_{+}$antistabil.

Berikutnya diberikan lemma yang bermanfaat untuk membuktikan syarat cukup dari Teorema 1.

Lemma 5. (Zhou, 1998) Terdapat kendali yang diperkenankan sedemikian sehingga $\left\|G_{z w}\right\|_{\infty}<\gamma$ jika dan hanya jika kondisi-kondisi berikut dipenuhi.

i. Terdapat solusi yang menstabilkan $X_{\infty}>0$ untuk persamaan

$$
X_{\infty} A+A^{*} X_{\infty}+X_{\infty}\left(B_{1} B_{1}^{*} / \gamma^{2}-B_{2} B_{2}^{*}\right) X_{\infty}+C_{1}^{*} C_{1}=0
$$

ii. Terdapat solusi yang menstabilkan $X_{\infty}>0$ untuk persamaan

$$
A Y_{\infty}+Y_{\infty} A^{*}+Y_{\infty}\left(C_{1}^{*} C_{1} / \gamma^{2}-C_{2} C_{2}^{*}\right) Y_{\infty}+B_{1} B_{1}^{*}=0
$$

iii. $\left[\begin{array}{cc}\gamma Y_{\infty}^{-1} & I_{n} \\ I_{n} & \gamma X_{\infty}^{-1}\end{array}\right] \geq 0 \quad$ atau $\rho\left(X_{\infty} Y_{\infty}\right)<\gamma^{2}$.

\section{Permainan Dinamis}

Permainan dinamis dapat dipandang sebagai generalisasi dari teori kendali. Konsep ini mempelajari situasi yang melibatkan konflik kepentingan antara dua atau lebih pengambil keputusan yang dapat berupa orang, organisasi maupun pemerintah. Pada permainan ini diasumsikan setiap pemain dapat mempengaruhi sejumlah variabel (yang berubah terhadap waktu) yang berperan penting dalam merealisasikan tujuan mereka. Diasumsikan pula dinamika pergerakan variabel terhadap waktu dapat disajikan dalam bentuk persamaan diferensial linear, yang berakibat tindakan yang dilakukan pemain juga linear terhadap variabel tersebut. Dalam permainan ini kesuksesan seorang pemain untuk merealisasikan tujuannya bergantung kepada strategi yang diambil oleh pemain lainnya. Sehingga informasi permainan menjadi hal penting dalam rangka menentukan tindakan optimal bagi setiap pemain.

Jenis permainan yang akan digunakan pada makalah ini adalah permainan dengan tipe informasi lingkar terbuka dan lingkar tertutup (feedback). Maksud dari permainan dengan tipe informasi lingkar terbuka adalah bahwa selama permainan berlangsung dalam waktu $t \in[0, T]$ setiap pemain hanya mengetahui state awal $x_{0}$ dan struktur model (bisanya dinotasikan dengan $\eta_{i}(t)=x_{0}, t \in[0, T]$ ). Skenario ini dapat diinterpretasikan dengan di awal permainan setiap pemain menentukan strateginya masingmasing secara serempak, kemudian mereka mendaftarkan strategi tersebut kepada bandar permainan yang akan menjalankan strategi tersebut secara konsisten (Engwerda Salmah, 2009). Sedangkan dalam permainan lingkar tertutup informasi yang dimiliki oleh masing-masing pemain adalah keseluruhan state dari sistem $\left(\eta_{i}(t)=x(t), t \in[0, T]\right.$ ) (Engwerda Salmah, 2011). Sehingga setiap pemain mengetahui tindakan/strategi yang diambil oleh pemain yang lain pada setiap waktu selama permainan berlangsung. Tipe permainan yang digunakan dalam makalah ini adalah permainan nonkooperatif yang berarti semua pemain tidak saling bekerja sama untuk mencapai tujuan mereka.

Persamaan matematika untuk permainan dinamis dengan $n$ pemain disajikan dalam bentuk persamaan diferensial linear

$$
\dot{x}=A x+B_{1} u_{1}+\ldots+B_{n} u_{n}, \quad x(0)=x_{0} .
$$


dengan $x \in \mathrm{R}^{n}, \quad A \in \mathrm{R}^{n \times n}, \quad B_{i} \in \mathrm{R}^{n \times m_{i}}, \quad u_{i} \in \mathrm{R}^{m_{i}}$. Setiap pemain mempunyai fungsi ongkos yang berbentuk kuadratik

$$
J_{i}\left(u_{1}, \ldots, u_{n}\right)=\int_{0}^{T}\left[x^{T} Q_{i} x+\sum_{j=1}^{n} u_{j}^{T} R_{i j} u_{j}\right] d t+x^{T}(T) Q_{i T} x(T), i=1 \ldots n
$$

dengan semua $Q_{i}, R_{i j}$ simetris dan matriks $R_{i j}$ definit positif.

Tujuan dari setiap pemain adalah meminimumkan fungsi ongkosnya masing-masing dengan memilih kendali yang sesuai pada sistem dinamik linear yang mendasarinya. Dalam hal ini didefinisikan: $\eta_{i}(t)$ dengan $t \in[0, T]$ adalah informasi yang dimiliki oleh pemain dalam suatu permainan, $\mathcal{M}_{i}$ adalah himpunan strategi-strategi / tindakan / kendali yang dimungkinkan dipilih pemain, dan $u_{i}=\mu_{i}\left(\eta_{i}\right)$ , dengan $\mu_{i} \in \mathcal{M}_{i}$ adalah tindakan atau kendali yang dipilih oleh pemain.

Tipe permainan yang diperlukan dalam makalah ini adalah permainan dinamis dua pemain berjumlah nol. Dalam tipe ini fungsi ongkos yang dimiliki oleh pemain kedua adalah negatif dari fungsi ongkos pemain pertama, sehinga jika kedua fungsi ongkos ini dijumlahkan akan menghasilkan nol. Persamaan matematis yang mengggambarkan situasi di atas adalah

$$
\dot{x}=A x+B_{1} u_{1}+B_{2} u_{2}, \quad x(0)=x_{0}
$$

Fungsi ongkos kuadratik untuk pemain pertama

$$
J_{1}\left(u_{1}, u_{2}\right)=\int_{0}^{T}\left[x^{T}(t) Q x(t)+u_{1}^{T}(t) R_{1} u_{1}(t)-u_{2}^{T}(t) R_{2} u_{2}(t)\right] d t+x^{T}(T) Q_{T} x(T),
$$

sedangkan fungsi ongkos kuadratik untuk pemain kedua adalah negatif dari fungsi ongkos kuadratik untuk pemain pertama

$$
J_{2}\left(u_{1}, u_{2}\right)=-J_{1}\left(u_{1}, u_{2}\right)
$$

dengan matriks $Q, Q_{T}$, dan $R_{i}, i=1,2$ adalah simetris. Lebih lanjut, diasumsikan $R_{i}, i=1,2$ definit positif.

Selanjutnya, keberadaan solusi bagi permainan dinamis dengan struktur informasi lingkar terbuka berjumlah nol untuk dua orang pemain diberikan oleh teorema berikut.

Teorema 6. (Engwerda, 2005), (Basar Olsder, 1999) Diberikan sebuah permainan dinamis dua orang pemain berjumlah nol yang didefinisikan pada sistem dinamik (4) dengan fungsi ongkos untuk pemain pertama (5) dan untuk pemain kedua (6). Maka, untuk semua $T \in\left[0, t_{1}\right]$ tipe permainan ini mempunyai ekuilibrium Nash (yang juga berarti ekuilibrium titik pelana) lingkar terbuka untuk setiap state awal jika dan hanya jika kondisi-kondisi di bawah ini dipenuhi.

i. Persamaan diferensial Riccati

$$
\dot{P}(t)=-A^{T} P(t)-P(t) A-Q+P(t)\left(S_{1}-S_{2}\right) P(t), \quad P(T)=Q_{T}
$$

mempunyai solusi simetris $P(0, T)$ untuk setiap $T \in\left[0, t_{1}\right]$.

ii. Dua persamaan diferensial Riccati

$$
\begin{aligned}
& \dot{K}_{1}(t)=-A^{T} K_{1}(t)-K_{1}(t) A+K_{1}(t) S_{1} K_{1}(t)-Q, \quad K_{1}(T)=Q_{T}, \\
& \dot{K}_{2}(t)=-A^{T} K_{2}(t)-K_{2}(t) A+K_{2}(t) S_{2} K_{2}(t)+Q, \quad K_{2}(T)=-Q_{T},
\end{aligned}
$$


mempunyai solusi $K_{i}(0, T)$ untuk setiap $T \in\left[0, t_{1}\right]$.

Lebih lanjut, jika kondisi di atas dipenuhi ekuilibrium Nash tersebut tunggal. Dalam hal ini ekuilibrium Nash diberikan oleh persamaan

$$
u_{1}^{*}=-R_{1}^{-1} B_{1}^{T} P \Phi(t, 0) x_{0} \text { dan } u_{2}^{*}=R_{2}^{-1} B_{2}^{T} P \Phi(t, 0) x_{0} .
$$

Fungsi $\Phi(t, 0)$ memenuhi persamaan transisi $\Phi(t, 0)=\left(A-\left(S_{1}-S_{2}\right) P\right) \Phi(t, 0) ; \quad \Phi(t, t)=I$.

Sistem dinamik setelah diberi kendali (strategi) optimal $\left(u_{1}^{*}, u_{2}^{*}\right)$ yaitu

$$
\dot{x}(t)=\left(A-\left(S_{1}-S_{2}\right) P\right) x(t), \quad x(0)=x_{0}
$$

adalah stabil dikarenakan $P$ adalah solusi yang menstabilkan sistem (7).

\section{Masalah Peredaman Gangguan Dengan Pendekatan Permainan Dinamis}

Diberikan sistem dinamik (1) dengan fungsi transfernya disajikan sebagai

$$
G_{\mu}(w)=\left[\begin{array}{ll}
G_{11} & G_{12} \\
G_{21} & G_{22}
\end{array}\right] .
$$

Fungsi transfer sistem (1) dari $w(t)$ ke $z(t)$ dalam bentuk linear fractional transformation (LFT) disajikan oleh persamaan

$$
\begin{aligned}
G_{z w}=F_{l}(G, \mu) & =G_{11}+G_{12}\left(I-\mu \cdot G_{22}\right)^{-1}\left(\mu \cdot G_{21}\right) \\
& :=G_{\mu}(w) .
\end{aligned}
$$

Masalah mendesain kendali robust dapat diformulasikan sebagai mencari semua pengontrol yang diperkenankan (admissible controllers) $\mu(t)$ sedemikian sehingga $\left\|G_{z w}\right\|_{\infty}<\gamma$, untuk suatu $\gamma$ yang diberikan. Dengan kata lain ingin dicari kendali $\mu \in \mathcal{M}$ yang akan mengoptimalkan penurunan tingkat ganguan pada keluaran sistem yang dirumuskan sebagai

$$
\inf _{\mu \in \mathcal{M}}\left\|G_{z w}\right\|_{\infty}
$$

Jika $\gamma^{*}$ adalah nilai optimal dari (8) maka dapat ditulis

$$
\gamma^{*}:=\inf _{\mu \in \mathcal{M}}\left\|G_{z w}\right\|_{\infty}
$$

Berdasarkan definisi norm operator (Horn dan Johnson, 1985) didapat

$$
\left\|G_{z w}\right\|=\sup _{\|w(t)\| \leq 1}\left\|G_{\mu}(w)\right\|=\sup _{w \in \mathcal{H}_{w}} \frac{\left\|G_{\mu}(w)\right\|}{\|w(t)\|} .
$$

Dengan demikian masalah peredaman gangguan dapat diformulasikan sebagai masalah mencari $\gamma^{*}$ dan $\mu^{*} \in \mathcal{M}$ yang bersesuaian yang akan meminimalkan $\left\|G_{z w}\right\|$, atau menyelesaikan masalah optimisasi (8), yaitu 


$$
\inf _{\mu \in \mathcal{M}}\left\|G_{z w}\right\|_{\infty}=\inf _{\mu \in \mathcal{M}} \sup _{w \in \mathcal{H}_{w}} \frac{\left\|G_{\mu}(w)\right\|}{\|w(t)\|}
$$

Persamaan (10) menyatakan nilai teratas permainan dinamis dua pemain, sehingga dipenuhi persamaan

$$
\inf _{\mu \in \mathcal{M}} \sup _{w \in \mathcal{H}_{w}} \frac{\left\|G_{\mu}(w)\right\|}{\|w(t)\|} \geq \sup _{w \in \mathcal{H}_{w}} \inf _{\mu \in \mathcal{M}} \frac{\left\|G_{\mu}(w)\right\|}{\|w(t)\|} .
$$

Jika terdapat $\mu^{*} \in \mathcal{M}$ dan $\gamma^{*}$ yang bersesuaian yang memenuhi batas penurunan tingkat ganguan $\gamma^{*}$ pada persamaan (9), maka masalah optimisasi (10) ekuivalen dengan masalah

i. Terdapat $\mu^{*} \in \mathcal{M}$ dan $\gamma^{*}$ sedemikian sehingga

$$
\left\|G_{\mu^{*}}(w)\right\|^{2} \leq \gamma^{* 2}\|w(t)\|^{2} \text {, untuk semua } w \in \mathcal{H}_{w}
$$

dan

ii. Tidak terdapat $\mu \in \mathcal{M}$ yang lain (katakan $\hat{\mu}$ ) dan $\hat{\gamma}<\gamma^{*}$ yang bersesuaian sedemikian sehingga

$$
\left\|G_{\hat{\mu}}(w)\right\|^{2} \leq \hat{\gamma}^{* 2}\|w(t)\|^{2} \text {, untuk semua } w \in \mathcal{H}_{w} .
$$

Selanjutnya didefinisikan keluarga fungsi ongkos berparameter (dalam $\gamma \geq 0$ )

$$
J_{\gamma}(\mu, w):=\left\|G_{\mu}(w)\right\|^{2}-\gamma^{2}\|w(t)\|^{2}
$$

Maka, masalah (i) dan (ii) di atas ekuivalen dengan masalah mencari nilai $\gamma \geq 0$ terkecil yang membuat nilai teratas permainan dengan fungsi ongkos $J_{\gamma}(\mu, w)$ terbatas ke atas pada nilai nol dan mencari kendali $\mu \in \mathcal{M}$ yang bersesuaian yang menghasilkan nilai teratas permainan. Selanjutnya, menggunakan definisi norm

$$
\begin{aligned}
\left\|G_{\mu}(w)\right\|^{2} & =\int_{0}^{\infty} z^{T}(t) z(t) d t \\
\|w(t)\|^{2} & =\int_{0}^{\infty} w^{T}(t) w(t) d t
\end{aligned}
$$

dan dengan mengasumsikan $C_{2}^{T} D_{21}=0$ dan $D_{21}^{T} D_{21}=I$ pada sistem dinamik (1) maka fungsi ongkos (11) dapat disajikan dalam bentuk linear kuadratik

$$
J_{\gamma}(u, w)=\int_{0}^{\infty}\left[x^{T}(t) Q x(t)+u^{T}(t) R_{1} u(t)-\gamma w^{T}(t) R_{2} w(t)\right] d t
$$

dengan $Q:=C_{1}^{T} C_{1}$, dan $R_{1}=R_{2}=I$. Dengan demikian maka masalah peredaman gangguan dapat diformulasikan ke dalam permainan dinamis linear kuadratis yang didefinisikan pada sistem dinamik (1) dengan fungsi ongkos untuk pemain pertama (desainer kendali) adalah (12) dan fungsi ongkos untuk pemain kedua (gangguan) adalah $-J_{\gamma}(u, w)$. 
Berikut diberikan teorema yang berguna untuk mencari nilai $\gamma^{*}$ dan kendali $\mu \in \mathcal{M}$ yang bersesuaian dalam permainan dengan struktur informasi lingkar terbuka.

Teorema 7. Diberikan masalah peredaman gangguan yang direpresentasikan sebagai permainan dinamis linear kuadratik dua pemain berjumlah nol dengan struktur informasi lingkar terbuka yang didefinisikan oleh persamaan dinamik (1), dengan fungsi ongkos pemain pertama diberikan oleh persamaan (4.11) dan fungsi ongkos pemain kedua adalah $-J_{\gamma}(u, w)$. Maka, hal-hal berikut dipenuhi:

i. Untuk $\gamma>\gamma^{*}$, persamaan aljabarRiccati

$$
0=-A^{T} P(t)-P(t) A-Q+P(t)\left(S_{1}-\frac{1}{\gamma} S_{2}\right) P(t),
$$

tidak mempunyai titik konjugat.

ii. Untuk $\gamma>\gamma^{*}$, permainan dinamis mempunyai solusi titik pelana yang diberikan oleh

$$
u^{*}(t)=-R_{1}^{-1} B_{1}^{T} P(t) x^{*}(t) \quad \text { dan } \quad w^{*}(t)=\frac{1}{\gamma^{2}} R_{2}^{-1} B_{2}^{T} P(t) x^{*}(t)
$$

dengan $P(t)$ adalah solusi persamaan (13) dan $x^{*}(t)$ adalah state trayektori yang dibangun oleh

$$
\dot{x}^{*}(t)=\left(A-\left(B_{1} B_{1}^{T}-\frac{1}{\gamma^{2}} B_{2} B_{2}^{T}\right) P(t)\right) x^{*}(t), x^{*}(0)=x_{0} .
$$

iii. Untuk $\gamma>\gamma^{*}$, nilai titik pelana permainan diberikan oleh

$$
J_{\gamma}^{*}(u, w)=x_{0}^{T} P(0) x_{0} .
$$

iv. Jika $\gamma<\gamma^{*}$, nilai teratas bagi permainan bernilai takterbatas untuk suatu $\left.x_{0} \in\right\lrcorner^{n}$. Lebih lanjut, terdapat suatu $x_{0} \in \sqcup^{n}$ sedemikian sehingga nilai teratas bagi permainan juga bernilai takterbatas, yaitu pada $\gamma=\gamma^{*}$.

\section{Simulasi Numerik}

Bagian ini akan menbandingkan desain kendali robust pada domain frekuensi yang sudah biasa dilakukan banyak orang dengan desain kendali robust melalui pendekatan permainan dinamis. Diberikan sistem LTI dengan realisasi fungsi transfer

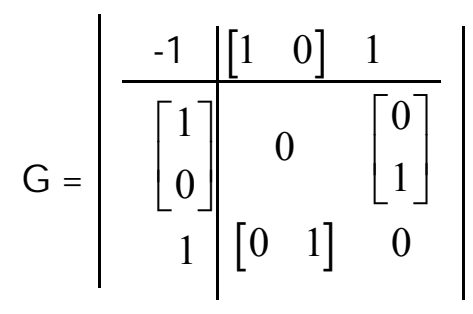

Tanpa mengurangi keumuman desain, diambil $\gamma=1$, dan dengan perhitungan sederhana diperoleh sistem di atas memenuhi asumsi-asumsi berikut:

1. $\left(A, B_{1}\right)$ terkendali dan $\left(C_{1}, A\right)$ terobservasi,

2. $\left(A, B_{2}\right)$ dapat distabilkan, dan $\left(C_{2}, A\right)$ dapat dideteksi, 
3. $D_{12}^{*}\left[\begin{array}{ll}C_{1} & D_{12}\end{array}\right]=\left[\begin{array}{ll}0 & I\end{array}\right]$,

4. $\left[\begin{array}{c}B_{1} \\ D_{21}\end{array}\right] D_{21}^{*}=\left[\begin{array}{l}0 \\ I\end{array}\right]$.

Selanjutnya dibentuk matriks Hamiltonian

$$
\begin{aligned}
& H_{\infty}=\left[\begin{array}{cc}
A & \gamma^{-2} B_{1} B_{1}^{*}-B_{2} B_{2}^{*} \\
-C_{1}^{*} C_{1} & -A^{*}
\end{array}\right] \quad \text { dan } \quad J_{\infty}=\left[\begin{array}{cc}
A^{*} & \gamma^{-2} C_{1}^{*} C_{1}-C_{2}^{*} C_{2} \\
-B_{1} B_{1}^{*} & -A
\end{array}\right] \\
& =\left[\begin{array}{ll}
-1 & 0 \\
-1 & 1
\end{array}\right] \quad=\left[\begin{array}{ll}
-1 & 0 \\
-1 & 1
\end{array}\right] \text {. }
\end{aligned}
$$

Nilai eigen dari $H_{\infty}$ adalah -1 dengan vektor eigen $\left(\begin{array}{l}2 \\ 1\end{array}\right)$ dan 1 dengan vektor eigen $\left(\begin{array}{l}0 \\ 1\end{array}\right)$. Maka, $X_{-}(H)=\operatorname{Im}\left[\begin{array}{l}X_{1} \\ X_{2}\end{array}\right]=\left(\begin{array}{l}2 \\ 1\end{array}\right)$ sehingga didapat $X_{\infty}=X_{2} X_{1}^{-1}=\frac{1}{2}$, dengan $X_{\infty}$ adalah solusi dari persamaan aljabar Riccati

$$
A^{*} X_{\infty}+X_{\infty} A+X_{\infty}\left(B_{1} B_{1}^{*}-B_{2} B_{2}^{*}\right) X_{\infty}+C_{1}^{*} C_{1}=0
$$

Dengan cara yang sama didapat $Y_{\infty}=\frac{1}{2}$, dimana $Y_{\infty}$ adalah solusi dari persamaan aljabar Riccati

$$
A Y_{\infty}+Y_{\infty} A+Y_{\infty}\left(C_{1}^{*} C_{1}-C_{2}^{*} C_{2}\right) Y_{\infty}+B_{1} B_{1}^{*}=0
$$

Sehingga $H_{\infty}, J_{\infty}$, dan $\left(X_{\infty}, Y_{\infty}\right)$ memenuhi

(i) $\quad H_{\infty} \in \operatorname{dom}(\mathrm{Ric}) \quad$ dan $\quad X_{\infty}=\operatorname{Ric}\left(H_{\infty}\right)=\frac{1}{2}>0$,

(ii) $J_{\infty} \in \operatorname{dom}($ Ric $) \quad$ dan $\quad Y_{\infty}=\operatorname{Ric}\left(J_{\infty}\right)=\frac{1}{2}>0$,

(iii) $\rho\left(X_{\infty} Y_{\infty}\right)=\frac{1}{4}<\gamma^{2}$.

Maka kendali robust dari sistem di atas adalah

$$
K_{s u b}(s)=\left|\begin{array}{c|c}
\hat{A}_{\infty} & -Z_{\infty} L_{\infty} \\
\hline F_{\infty} & 0
\end{array}\right|
$$

dengan $\quad F_{\infty}=-B_{2}^{*} X_{\infty}=-\frac{1}{2}, \quad L_{\infty}=-Y_{\infty} C_{2}^{*}=-\frac{1}{2}, \quad Z_{\infty}=\left(I-\gamma^{-2} Y_{\infty} X_{\infty}\right)^{-1}=\frac{4}{3}$,

dan $\hat{A}_{\infty}=A+\gamma^{-2} B_{1} B_{1}^{*} X_{\infty}+B_{2} F_{\infty}+Z_{\infty} L_{\infty} C_{2}=-\frac{5}{3}$. 
Sehingga didapat

$$
K_{s u b}(s)=\left|\frac{5 / 3}{3}\right| \frac{2}{3}|-|=-\frac{1}{3 s+5}
$$

Untuk memperoleh kendali suboptimal $u(t)$, inverskan transformasi Laplace dari fungsi $-\frac{1}{3 s+5}$ sehingga diperoleh

$$
L^{-1}\left\{-\frac{1}{3 s+5}\right\}=-\frac{1}{3} e^{-\frac{5}{3} t}
$$

Jadi diperoleh kendali suboptimal robust

$$
u(t)=-\frac{1}{3} e^{-5 / 3 t}
$$

Selanjutnya, akan dicari kendali suboptimal sistem (14) dengan menggunakan metode permainan dinamis. Diambil $Q=C_{1}^{T} C_{1}=1, R_{1}=R_{2}=1$, sehingga diperoleh fungsi ongkos untuk permainan

$$
J(u, w)=\int_{0}^{\infty}\left\{x^{T}(t) Q x(t)+u^{T}(t) u(t)-w^{T}(t) w(t)\right\} d t .
$$

Diperoleh matriks $M$ untuk permainan dengan entri-entrinya adalah

$$
M=\left[\begin{array}{ccc}
-1 & -1 & -1 \\
-1 & 1 & 0 \\
1 & 0 & 1
\end{array}\right],
$$

dengan nilai eigen dari $M$ adalah -1 dengan vektor eigen $\left[\begin{array}{c}0.8165 \\ 0.4082 \\ -0.4082\end{array}\right]$ dan 1 dengan vektor eigen $\left[\begin{array}{c}0 \\ -0.7071 \\ 0.7071\end{array}\right]$. Dengan demikian diperoleh $P_{1}=0.4082 \cdot \frac{1}{0.8165}=0.5$ dan $P_{2}=-0.4082 \cdot \frac{1}{0.8165}=-0.5$.

Sistem setelah diberi kendali optimal diberikan oleh

$$
\begin{aligned}
& \dot{x}(t)=\left(A-S_{1} P_{1}-S_{2} P_{2}\right) x(t) \\
& \dot{x}(t)=-2 x(t)
\end{aligned}
$$

Sehingga didapat trayektori optimal $x(t)=e^{-2 t}$ yang stabil. Dengan demikian didapat kendali optimal

$$
\begin{aligned}
u^{*}(t) & =-R_{1}^{-1} B_{1}^{T} P_{1} x(t) \\
& =-\frac{1}{2} e^{-2 t}
\end{aligned}
$$


Persamaan (15) dan (16) merupakan kendali yang robust bagi sistem (14) dikarenakan trayektori setelah diberi kendali adalah trayektori yang stabil.

\section{Kesimpulan}

Dalam makalah ini telah dikaji desain kendali robust melalui pendekatan permainan dinamis. Teorema teorema terkait dengan desain kendali dan batas terkecil parameter $\gamma$ telah dipaparkan. Makalah ini juga telah menyajikan perbandingan hasil desain kendali robust antara pendekatan domain frekuensi dengan permainan dinamis, dimana keduanya mmenuhi kriteria robust. Namun demikian permasalahan dalam kajian ini masih cukup sederhana. Sehingga pengembangan permasalahan seperti desain kendali robust pada suatu sistem singular (sistem deskriptor) dapat menjadi bahan kajian lebih lanjut.

\section{Ucapan Terimakasih}

Penulis mengucapkan terima kasih kepada Lembaga Penelitian dan Pengabdian kepada Masyarakat Universitas Islam Negeri Sunan Kalijaga atas pemberian dana hibah penelitian sehingga penelitian dan penulisan artikel ini dapat diselesaikan.

\section{Referensi}

[1] Basar, T. dan Bernhard, P., 1995, $\mathcal{H}_{\infty}$ Optimal Control and Related Minimax Design Problems: Dynamic Game Approach, Birkhauser, Boston.

[2] Basar, T. dan Olsder, G.J., 1999, Dynamic Noncooperative Game Theory, Acadmic Press SIAM, New York.

[3] Engwerda, J.C., 2005, LQ Dynamic Optimization and Differential Game, John Wiley \& Sons, Ltd., England.

[4] Engwerda, J.C. dan Salmah, 2009, The Open-Loop Linear Quadratic Differential Game for Index One Descriptor Systems, Automatica, vol. 45 no. 2, 585-592.

[5] Engwerda, J.C. dan Salmah, 2011, Feedback Nash Equilibria for Linear Quadratic Descriptor Differential Game, proses submisi ke jurnal Sciense Direct.

[6] Horn, R.A., dan Johnson, C.A., 1985, Matrix Analysis, Cambridge University Press, Cambridge.

[7] Xu, S. dan Lam J., 2006, Robust Control and Filtering of Singular Systems, Springer, Berlin.

[8] Zhou K., Doyle, J.C., 1998, Essentials of Robust Control, Prentice-Hall, New Jersey. 